\title{
Pengembangan Modul Pembelajaran Teknik Kerja Bengkel sebagai Bahan Ajar Kelas X Teknik Audio Video
}

\author{
Fariz Budi Widada ${ }^{1}$, Sri Waluyanti ${ }^{2}$ \\ 1,2Program Studi Pendidikan Teknik Elektronika \\ E-mail: farizbudiwidada@gmail.com
}

\begin{abstract}
The 2013 curriculum encourages the development of instructional media that can encourage the creation of more effective learning and support students to be creative. This research aims to determine the steps to develop a workshop technique module for learning and satisfying process for learning. This learning module is used in workshop technique, subject class X skill competency audio-video technique in SMK Muhammadiyah 3 Yogyakarta. This research using method Research and Development $(R \& D)$ version Borg and Gallyang have been simplified by Anik Ghufron with 4 steps: 1) introduction study; 2) Development; 3) experiment test; 4) disseminate. The result of the research shows from the validation material expertise has score 3,40 and claimed very satisfy, validation for media expertise has score 3,75 and claimed very satisfy. Meanwhile, the result for experiment test get score 3,20 and claimed to satisfy. Consideration from validation result and experiment test, thus learning module is developed satisfy for used on process workshop technique learning.
\end{abstract}

Keywords: learning module, audio-video technique, workshop technique

\begin{abstract}
ABSTRAK
Kurikulum 2013 mendorong adanya pengembangan media pembelajaran yang dapat mendorong terciptanya pembelajaran yang lebih efektif dan mendukung peserta didik menjadi kreatif. Penelitian ini bertujuan untuk mengetahui langkah-langkah mengembangkan modul pembelajaran Teknik Kerja Bengkel dan mengetahui kelayakannya. Modul pembelajaran in digunakan pada mata pelajaran Teknik Kerja Bengkel Kelas X Kompetensi keahlian Teknik Audio Video di SMK Muhammadiyah 3 Yogyakarta. Penelitian ini menggunakan metode Research and Development (R\&D) versi Borg dan Gall yang telah disederhanakan oleh Anik Ghufron. dengan 4 tahapan: (1) studi pendahuluan; (2) pengembangan; (3) uji lapangan; dan (4) desiminasi. Hasil penelitian menunjukan bahwa dari validasi ahli materi memperoleh skor 3,40 dan dinyatakan sangat layak, validasi dari ahli media memeperoleh skor 3,75 dan dinyatakan sangat layak, sementara hasil uji lapangan memperoleh skor 3,20 dan dinyatakan layak. Berdasarkan dari hasil validasi dan uji lapangan maka modul pembelajaran yan dikembangkan layak digunakan dalam proses pembelajaran Mata Pembelajaran Teknik Kerja Bengkel.
\end{abstract}

Kata kunci: modul pembelajaran, teknik audio video,teknik kerja bengkel

\section{PENDAHULUAN}

Dalam rangka tercapainya tujuan pendidikan memerlukan adanya kegiatan belajar mengajar (KBM) yang mengembangkan perilaku inovatif, kreatif, dan berkeinginan maju supaya tumbuh budaya belajar mengajar di masyarakat. Pembelajaran yang sebagian besar berorientasi pada ilmu praktis memerlukan media pembelajaran. Media pembelajaran mempunyai pengaruh yang besar terhadap proses pembelajaran khususnya bagi peserta didik. Melalui penggunaan media pembelajaran diharapkan peserta didik lebih cepat dan mudah dalam memahami materi yang disampaikan oleh pendidik dalam proses pembelajaran.

Sekolah Menengah Kejuruan (SMK) Muhammadiyah 3 Yogyakarta adalah salah satu sekolah swasta yang sudah menerapkan manajemen ISO 9001:2015. SMK Muhammadiyah 3 Yogyakarta diharapkan mampu mencetak lulusan yang berkualitas serta 
dapat memenuhi kebutuhan industri. Penerapan manajemen mutu yang berkualitas merupakan bagian dari pengelolaan pendidikan yang berkualitas. Pengelolaan pendidikan tersebut yang diharapkan mampu menciptakan dan meningkatkan SDM yang berkualitas. SMK Muhammadiyah 3 Yogyakarta telah menerapkan Kurikulum 2013 dari tahun 2013. Perubahan dari Kurikulum Tingkat Satuan Pendidikan (KTSP) menjadi Kurikulum 2013 menuntut guru untuk menyelengarakan pembelajaran menjadi lebih efektif serta menuntut siswa menjadi lebih kreatif. Kurangnya media berupa buku atau pegangan dalam proses pembelajaran dirasa sebagai salah satu penghambat dalam proses pembelajaran siswa SMK kompetensi keahlian Teknik Audio Video. Media pembelajaran merupakan salah satu aspek yang dapat digunakan guru kejuruan untuk menghadapi komunitas ekonomi ASEAN [1]. Media instruksional dalam pendidikan kejuruan telah dikembangkan [2], [3]. Masing-masing media tersebut memiliki karakteristik yang spesifik untuk materi tertentu.

Permasalahan yang ditemui peneliti berdasarkan pengalaman PPL dan wawancara dengan guru adalah keterbatasan media pembelajaran yang digunakan dalam proses pembelajaran yang disebabkan karena perubahan kurikulum dari KTSP menjadi Kurikulum 2013. Selain itu juga siswa belum bisa belajar secara mandiri dan masih bergantunng pada kehadiran dan sumber materi dari guru saja. Di abad ke-21 ini, para pendidik, terutama dalam pendidikan kejuruan, perlu mengembangkan alat bantu mengajar yang dapat mengintegrasikan keterampilan abad ke-21 dalam penguasaan materi sesuai kompetensi keahlian secara teknis [4]. Tambahan, media pembelajaran merupakan salah satu indikator kompetensi pedagogik pendidik [5]. Menilik dari urgensi dan kebutuhan pengembangan media pembelajaran, maka diperlukan pengembangan media pembelajaran. Rumusan masalah pada penelitian ini adalah (1) bagaimana menyusun Modul Pembelajaran Teknik Kerja Bengkel Sebagai Bahan Ajar
Kelas X Teknik Audio Video di SMK Muhammadiyah 3 Yogyakarta; dan (2) bagaimana kelayakan Modul Pembelajaran Teknik Kerja bengkel yang telah dibuat sebagai bahan ajar kelas X Teknik Audio Video di SMK Muhammadiyah 3 Yogyakarta.

Salah satu upaya untuk mengatasi masalah tersebut adalah perlunya disusun sebuah modul yang disesuaikan dengan kondisi serta sarana dan prasarana di sekolah. Oleh karena itu perlunya dikembangkan modul untuk menunjang pembelajaran. Berdasarkan uraian tersebut maka penulis akan mengembangkan modul teknik kerja bengkel pada fokus masalah pembuatan PCB dan soldering desoldering. Modul ini merupakan bahan ajar yang disusun secara sistematis dan terstruktur untuk mencapai kompetensi yang memacu siswa belajar secara mandiri. Dengan adanya modul pembelajaran ini diharapkan dapat membantu peerta didik dan guru melaksanakan proses pembelajaran yang efektif. Tujuan penelitian ini adalah untuk mengembangkan dan mengetahui kelayakan modul pembelajaran dan dapat diterapkan pada pembelajaran Teknik Kerja Bengkel Kelas X Teknik Audio Video di SMK Muhammadiyah 3 Yogyakarta.

Pengembangan dapat diartikan memperdalam dan memperluas pengetahuan yang telah ada. Pada hakikatnya pengembangan adalah upaya pendidikan baik formal maupun non formal yang dilaksanakan secara sadar, berencana, terarah, teratur dan bertanggung jawab dalam rangka memperkenalkan, menumbuhkan, membimbing, mengembangkan suatu dasar kepribadian yang seimbang, utuh, selaras, pengetahuan, keterampilan sesuai bakat, keinginan serta kemampuankemampuan, sebagai bekal atas prakarsa sendiri untuk menambah, meningkatkan, mengembangkan diri kearah tercapainya martabat, mutu dan kemampuan manusiawi yang optimal serta pribadi mandiri [6].

Bahan ajar adalah seperangkat sarana atau alat pembelajaran yang berisikan materi pembelajaran, metode, batasan-batasan dan cara mengevaluasi yang didesain secara 
sistematis dan menarik dalam rangka mencapai tujuan yang diharapkan, yaitu mencapai kompetensi atau subkompetensi dengan segala kompleksitasnya [7]. Modul merupakan jenis kesatuan kegiatan belajar yang terencana, dirancang untuk membantu para siswa secara individual dalam mencapai tujuan belajar dan modul juga bisa dipandang sebagai paket program pengajaran yang terdiri dari komponen yang berisiskan tujuan belajar, bahan pelajaran, metode belajar, alat atau media, serta sumber belajar dan sistem evaluasinya [8].

\section{METODE}

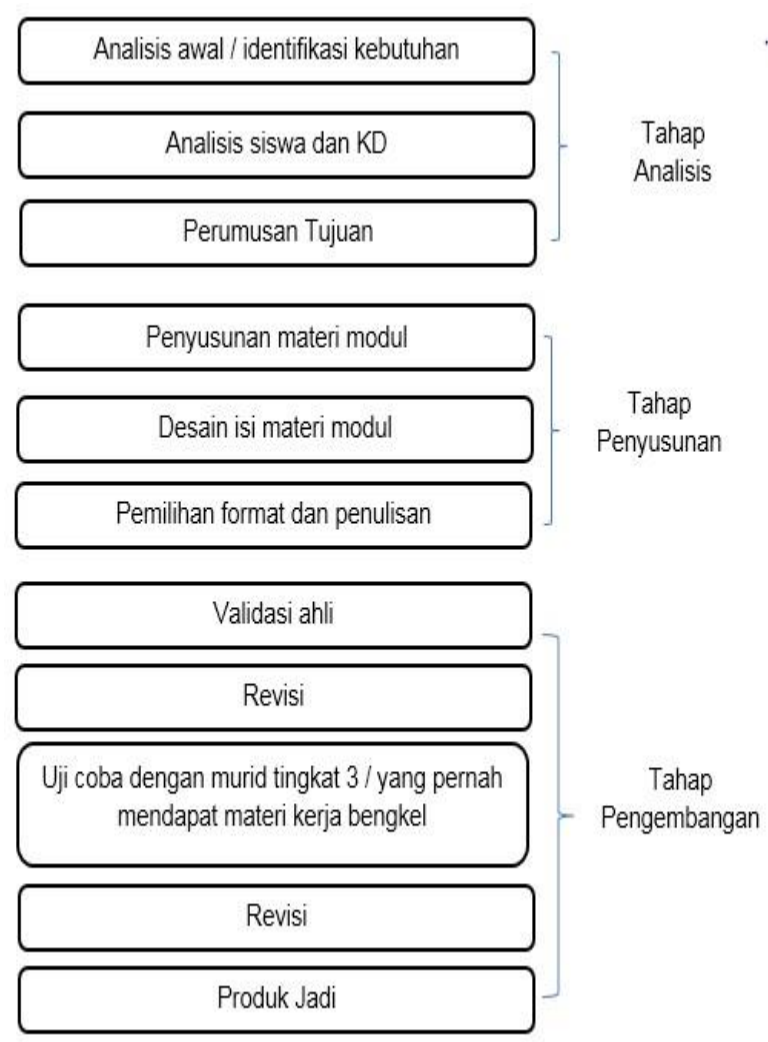

Gambar 1. Langkah-langkah pada tahapan pengembangan

Penelitian pengembangan ini juga disebut resacrh and developmen (R\&D). Pendekatan penelitian ini merupakan pengembangan dengan model pengembangan Borg dan Gall yang telah diadaptasi oleh Ghufron dkk menjadi empat tahapan, yaitu pendahuluan, pengembangan, uji lapangan dan diseminasi [9]. Studi pendahuluan dalam penelitian ini berupa observasi dan wawancara mengenai aspek kurikulum, penggunaan media pembelajaran, dan fakta permasalahan dilapangan. Tahapan pengembangan mengacu pada langkah-langkah penyusunan modul menurut Daryanto seperti pada Gambar 1 [10]. Tahapan uji lapangan dilakukan penerapan produk yang sudah dirancang. Tahapan terakhir adalah diseminasi.

Analisis kebutuhan modul dilakukan untuk mengidentifikasi dan menetapkan jumlah materi dan judul modul yang akan dikembangkan. Desain modul dilakukan dengan cara menyusun dan mengorganisasikan materi pembelajaran untuk mencapai kompetensi yang sudah ditentukan. Implementasi dilakukan dalam kegiatan pembelajaran. Penilaian dimaksudkan untuk mengetahui tingkat kepuasan peserta didik seletah menggunakan modul. Validasi bertujuan untuk mengetahui tingkat kelayakan dari ahli media dan ahli materi dari modul yang dikembangkan. Evaluasi dimaksudkan untuk mengetahui tingkat efektifitas penggunaan secara periodik dan dilakukan oleh ahli serta dapat dilakukan penyempurnaan ketika dirasa kurang sesuai dengan kebutuhan. Jaminan kualitas dilakukan untuk menjamin bahwa modul yang dibuat telah memenuhi ketentuan-ketentuan yang ditetapkan dalam pengembangan suatu modul.

Penelitian dilakukan pada bulan Februari hingga Maret 2019 yang dilaksanakan di SMK Muhammadiyah 3 Yogyakarta. Subjek penelitian ini terdiri dari dua macam, yaitu responden ahli dan responden pengguna. Resonden ahli terbagi menjadi dua yaitu ahli materi masing-masing dua ahli dan ahli media yang juga terdiri dari dua ahli. Responden pengguna terdiri dari 30 siswa kelas $\mathrm{X}$ kompetensi keahlian Teknik Audio Video SMK Muhammadiyah 3 Yogyakarta pada semester genap 2018/2019.

Prosedur pengembangan meliputi tahap penelitian dan pengumpulan informasi, tahap perencanaan, tahap pengembangan bentuk awal, tahap uji coba, tahap revisi dan diseminasi serta implementasi. Tahap penelitian dan 
pengumpulan data dilakukan dengan beberapa analisis seperti studi lapangan dan observasi. Tahapan pengembangan awal adalah pembuatan kerangka modul sesuai dengan analisis dan desain rancangan. Tahapan uji lapangan dan revisi produk yaitu pada pengujian kegunaan dan keefektifan modul sehingga sesuai dengan standar yang ditentukan. Dengan data yang didapatkan maka dapat diolahdan dilakukan perbaikan terhadap produk yang dihasilkan.

Data berisi hasil kuiesioner tentang kelayakan yang diperoleh dari ahli materi dan ahli media dari produk yang dikembangkan berupa modul pembelajaran. Selain data dari ahli diperoleh pula data kuesioner dari siswa yang kemudian diolah dan dapat menentukan kualitas produk. Instrumen dalam penelitian ini terbagi menjadi 3 (tiga) bagian, yaitu: instrumen untuk ahli materi, isntrumen untuk ahli media, dan respon siswa. Skala yng digunakan adalah skala linkert dengan emppat alternatif jawaban untuk ahli materi, ahli media, yaitu sangat baik, baik, kurang baik, dan tidak baik. Sementara untuk respon dari siswa menggunakan empat alternatif jawaban yaitu sangat setuju, setuju, kurang setuju, dan tidak setuju. Teknik pengumpulan data penelitian ini mengunakan metode angket untuk menilai kesesuaian modul pembelajaran yang dikembangkan dengan tujuan yang telah ditetapkan. Nilai yang diperoleh menentukan kelayakan modul pembelajaran.

Penelitian dan pengembangan modul teknik kerja bengkel ini menggunakan teknik analisa data deskriptif. Data penelitian dikelompokan menjadi dua, yaitu deskriptif dan kuantitatif. Data deskriptif kuantitatif yang berbentuk angka dan dijabarkan menggunakan statistik deskriptif dengan mengukur nilai rerata. Data deskriptif kuantitatif dinyatakan dengan pernyataan atau simbol. Data kuantitatif diperoleh dari penjabaran data kualitatif berdasarkan kriteria skor penilaian Tabel 1 dan Tabel 2. Kemudian data yang telah dihitung reratanya ditentukan klasifikasi kategori kelayakannya berdasarkan Tabel 3.
Tabel 1. Skor pertanyaan Ahli

\begin{tabular}{ccc}
\hline No & Jawaban Ahli & Skor Pertanyaan \\
\hline 1 & SB (Sangat Baik) & 4 \\
2 & B (Baik) & 3 \\
3 & KB (Kurang Baik) & 2 \\
4 & TB (Tidak Baik) & 1 \\
\hline
\end{tabular}

Tabel 2. Skor pertanyaan siswa

\begin{tabular}{ccc}
\hline No & Jawaban & Skor Pertanyaan \\
\hline 1 & SS (Sangat Setuju) & 4 \\
2 & S (Setuju) & 3 \\
3 & KS (Kurang Setuju) & 2 \\
4 & TS (Tidak Setuju) & 1 \\
\hline
\end{tabular}

Tabel 3. Kategori kelayakan

\begin{tabular}{ccl}
\hline No & Jawaban Ahli & \multicolumn{1}{c}{ Skor Pertanyaan } \\
\hline 1 & $>3,25 \mathrm{~s} / \mathrm{d} 4,00$ & $\begin{array}{l}\text { Sangat Layak/Sangat } \\
\text { Baik }\end{array}$ \\
2 & $>2,50 \mathrm{~s} / \mathrm{d} 3,25$ & Layak/Baik \\
3 & $>1,75 \mathrm{~s} / \mathrm{d} 2,50$ & $\begin{array}{l}\text { Cukup Layak/Cukup } \\
\text { Baik } \\
\text { Tidak Layak/Tidak } \\
\text { Baik }\end{array}$ \\
4 & $1,00 \mathrm{~s} / \mathrm{d} \mathrm{1,75}$ & \begin{tabular}{l} 
\\
\hline
\end{tabular}
\end{tabular}

Validasi dilakukan pada dua aspek yaitu validasi ahli materi dan ahli media dengan langsung mengkomukasikan dengan para ahli dibidangnya dan dalam hal ini adalah guru dan dosen.

\section{HASIL DAN PEMBAHASAN}

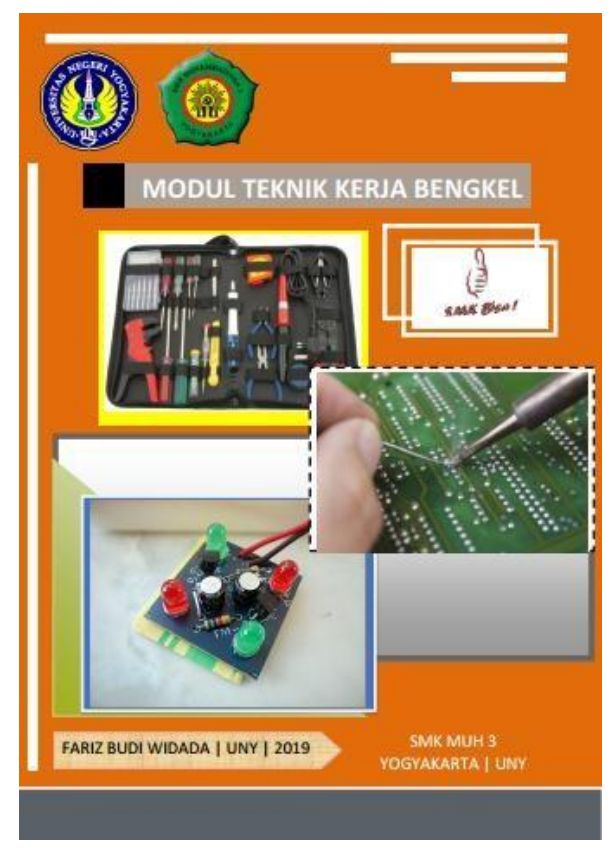

Gambar 2. Modul Kerja Bengkel 
Produk yang dihasilkan pada pengembangan modul ini adalah berupa modul pembelajaran yang dibuat berdasarkan kebutuhan bahan ajar pada mata pelajaran Teknik Kerja Bengkel. Berdasarkan materi pembelajaran yang dibutuhkan dan hasil dari observasi di SMK Muhammadiyah 3 Yogyakarta maka dihasilkan rencana pengembangan yang menjadi dasar pengembangan modul pembelajaran. Modul kerja bengkel ini memuat beberapa unsur, berupa: (1) tujuan pembelajaran, (2) uraian materi, (3) rangkuman, (4) pertanyaan, (5) tugastugas dan (6) jawaban pertanyaan.

Presentase kelayakan modul ini berasal dari dua ahli materi dan dua ahli media. Untuk penilaian ahli materi, jumlah rerata skor tiap aspek dari aspek self intruction, aspek self contained, aspek stand alone, aspek adaptive dan aspek user friendly adalah 3,39 dari nilai skor maksimum 4 sehingga termasuk "sangat layak". Untuk penilaian ahli media jumlah rerata skor tiap aspek dari aspek format, organisasi, daya tarik, bentuk dan huruf, ruang (spasi kosong) dan konsisten adalah 3,75 dari nilai skor maksimum 4 sehingga termasuk "sangat layak". Setelah dinyatakan layak oleh ahli materi dan ahli media maka modul ini diujicobakan untuk mendapatkan respon dari siswa kelas XII dengan jumlah siswa 12 orang kompetensi dasar Teknik Audio Video di SMK Muhammadiyah 3 Yogyakarta sebagai tahapan uji uawal dan utama. Serta 30 orang kelas $\mathrm{X}$ sebagai uji oprasional siswa Kompetendi dasar Teknik Audio Video SMK Muhamadiyah 3 Yogyakarta.

Peniliaian siswa terdiri atas uji awal, uji utama dan uji oprasional. Jumlah rerata skor tahapan uji lapangan berdasarkan uji coba lapangan awal, uji coba lapangan utama, uji coba lapangan oprasional adalah 3,17 dan dikatakan layak digunakan pada mata pelajaran teknik kerja bengkel di SMK Muhmmadiyah 3 Yogyakarta dan diharapkan dapat membantu guru dalam penyampaian materi dan juga diharapkan peserta didik dapat belajar secara aktif dan mandiri. Sementara dalam pengukuran validitas diperoleh dari nilai $r$ hitung kemudian dibandingkan dengan $r$ pada tabel $r$ pada taraf signifikansi 5\%. $\mathrm{r}$ tabel pada taraf signifikansi 5\% untuk jumlah responden 30 adalah 0,3601. Butir instrumen dinyatakan valid jika $r$ hitung > $r$ tabel. Tabel 4 menunjukkan hasil nilai rhitung. Penghitungan tingkat reliabilitas menggunakan Rumus Alpha dan menggunakan skala Likert dengan model empat pilihan jawaban. Perhitungan menggunakan bantuan software SPSS 21. Hasil perhitungan reliabilitas instrumen (nilai cronbach's alpha) adalah 0,817 .

Tabel 4. Nilai rhitung

\begin{tabular}{cccc}
\hline No & r hitung & r tabel & Keterangan \\
\hline 1. & 0,384 & 0,3601 & Valid \\
2. & 0,377 & 0,3601 & Valid \\
3. & 0,376 & 0,3601 & Valid \\
4. & 0,374 & 0,3601 & Valid \\
5. & 0,363 & 0,3601 & Valid \\
6. & 0,396 & 0,3601 & Valid \\
7. & 0,563 & 0,3601 & Valid \\
8. & 0,410 & 0,3601 & Valid \\
9. & 0,376 & 0,3601 & Valid \\
10. & 0,709 & 0,3601 & Valid \\
11. & 0,535 & 0,3601 & Valid \\
12. & 0,508 & 0,3601 & Valid \\
13. & 0,466 & 0,3601 & Valid \\
14. & 0,447 & 0,3601 & Valid \\
15. & 0,498 & 0,3601 & Valid \\
16. & 0,411 & 0,3601 & Valid \\
17. & 0,448 & 0,3601 & Valid \\
18. & 0,369 & 0,3601 & Valid \\
19. & 0,362 & 0,3601 & Valid \\
20. & 0,372 & 0,3601 & Valid \\
21. & 0,427 & 0,3601 & Valid \\
22. & 0,409 & 0,3601 & Valid \\
23. & 0,405 & 0,3601 & Valid \\
24. & 0,445 & 0,3601 & Valid \\
25. & 0,497 & 0,3601 & Valid \\
26. & 0,467 & 0,3601 & Valid \\
27. & 0,445 & 0,3601 & Valid \\
28. & 0,454 & 0,3601 & Valid \\
29. & 0,543 & 0,3601 & Valid \\
30. & 0,421 & 0,3601 & Valid \\
\hline & & & \\
\hline
\end{tabular}

\section{SIMPULAN}

Berdasarkan hasil penelitian dan pembahasan, maka diperoleh simpulan sebagai berikut: (1) modul berbentuk cetak dengan ukuran kertas A4. Sistematika modul pembelajaran ini terdiri dari kompetensi dasar, tujuan pembelajaran, uraian materi, rangkuman materi, soal-soal dan lembar kerja. Pokok pembahasan modul ini adalah materi tentang pembuatan PCB serta proses soldering dan 
desoldering. Terdapat gambar-gambar pendukung yang tujuannnya untuk lebih memperjelas materi yang disampaikan dalam proses pembelajaran; (2) Kelayakan Modul Teknik kerja Bengkel ini telah dinyatakan layak untuk digunakan dalamm proses pembelajaran kelas X jurusan TAV SMK Muhammadiyah 3 Yogyakarta dengan berpatokan pada: (a) Berdasarkan hasil penilaian kelayakan modul menurut para ahli materi yang meliputi aspek self intruction, self contained, stand alone, adaptive, user friendly mencapai nilai rata-rata 3,39 dengan nilai maksimum 4 dan dinyatakan sangat layak digunakan dalam pembelajaran; (b) Berdasarkan hasil penilaian kelayakan modul menurut para ahli media yang meliputi aspek format, organisasi, daya tarik, bentuk dan ukuran huruf, ruang kosong dan aspek konsistensi mencapai nilai rata-rata 3,75 dengan nilai maksimum 4 dan dinyatakan sangat layak untuk digunakan dalam pembelajaran; (c) Berdasarkan penilaian keseluruhan aspek angket yang telah diisi oleh peserta didik mecapai nilai rata-rata 3,16 dari nilai maksimum 4, sehingga dapat disimpulkan bahwa kualitas produk yang dikembangkan adalah baik digunakan dalam pembelajaran. Hasil penelitian ini terbatas membahas metode yang digunakan dalam pengembangan modul pembelajaran. Uji kelayakan dan uji lapangan menjadi dasar penggunaan modul, namun yang perlu diketahui bahwa modul pembelajaran harus selalu diuji kelayakannya, karena setiap saat silabus berubah mengikuti tuntutan perkembangan jaman. Peneliti juga berharap bahwa modul ini dapat diuji melalui penelitian lainnya.

\section{DAFTAR PUSTAKA}

[1] F. J. Tasiam, "North Sulawesi electrical engineering teachers competence in facing ASEAN economic community," Int. J. Mech. Eng. Technol., vol. 9, no. 10, pp. 1603-1612, 2018.

[2] P. Sihombing and D. R. P. Sitompul, "A teaching media of using the busy bit and SDCC in displaying character string on LCD in $\mathrm{MCU}$ 8051 IDE," Alexandria Eng. J., vol. 57, no. 2, pp. 813-818, 2018.

[3] M. S. Zuhrie1, I. Basuki, B. I. G. P. Asto, and L. Anifah, "Design of Smart Educational Robot as a Tool For Teaching Media Based on Contextual Teaching and Learning to Improve the Skill of Electrical Engineering Student," IOP Conf. Ser. Mater. Sci. Eng., vol. 336, no. 012047, 2018.

[4] P. Utami, G. P. Cikarge, M. E. Ismail, and S. Hashim, "Teaching Aids in Digital Electronics Practice through Integrating 21st Century Learning Skills using a conceptual approach," in Journal of Physics: Conf. Series, 2018, pp. 1-9.

[5] B. Destiana and P. Utami, "Urgensi Kompetensi Pedagogik Guru Vokasional pada Pembelajaran Abad 21," Elinvo (Electronics, Informatics, Vocat. Educ., vol. 2, no. 2, pp. 211-222, 2017.

[6] Sugiyono, Metode Penelitian Kuantitatif Kualitataif dan Kombinasi (Mixed Methods). Bandung: Alfabeta, 2016.

[7] C. Widodo and Jasmadi, Panduan menyusun bahan ajar berbasis kompetensi. Jakarta: PT Alex Media Komputindo, 2008.

[8] Sudjana and Rivai, Teknologi Pengajaran. Bandung: Sinar Baru Algesindo, 2007.

[9] A. Ghufron dkk, Panduan Penelitian dan Pengembangan Bidang Pendidikan dan Pembelajaran. Yogyakarta: LPPM UNY, 2007.

[10]Daryanto, Menyusun modul bahan ajar untuk persiapan guru dalam mengajar. Yogyakarta: Gavamedia, 2013. 